\title{
Factors affecting the performance of double chamber microbial fuel cell for simultaneous wastewater treatment and power generation
}

\author{
Maksudur R. Khan ${ }^{1,2}$, M.S.A. Amin ${ }^{2 *}$, M.T. Rahman'2, F. Akbar ${ }^{2}$, K. Ferdaus ${ }^{2}$ \\ ${ }^{1}$ University Malaysia Pahang, Department of Chemical and Natural Resources Engineering, 26300 Gambang, Pahang, Malaysia \\ ${ }^{2}$ Shahjalal University of Science and Technology, Department of Chemical Engineering and Polymer Science, Sylhet-3114, \\ Bangladesh \\ "Corresponding author: saikat_cep@yahoo.com
}

\begin{abstract}
Electricity generation from the readily biodegradable organic substrate (glucose) accompanied by decolorization of azo dye was investigated using a two-chamber microbial fuel cell (MFC). Batch experiments were conducted to study the effect of dye and substrate concentration on MFC performance. Electricity generation was not significantly affected by the azo dye at $300 \mathrm{mg} / \mathrm{L}$, while higher concentrations inhibited electricity generation. The chemical oxygen demand (COD) removal and decolorization of dye containing wastewater used in the MFC were studied at optimum operation conditions in anode and cathode, $57 \%$ COD removal and $70 \%$ dye removal were achieved. This study also demonstrated the effect of different catholyte solutions, such as $\mathrm{KMnO}_{4}$ and $\mathrm{K}_{2} \mathrm{Cr}_{2} \mathrm{O}_{7}$ on electricity generation. As a result, $\mathrm{KMnO}_{4}$ solution showed the maximum electricity generation due to its higher standard reduction potential.
\end{abstract}

Keywords: Catholyte, COD, Microbial Fuel Cell, Wastewater treatment.

\section{INTRODUCTION}

Sustainable energy production and wastewater treatments are the top priority in the developing global community. Many industrially developed or developing countries had a lot of problems to treat some of the industrial waste materials, which cause pollution to the environment. Due to the rapid industrialization, Bangladesh cannot be far away from this environmental pollution. Among all, textile is one of the largest and vital industrial sectors of Bangladesh with regard to earning foreign exchange and labor employment. This sector provides 4.5 million jobs of which $80 \%$ are women and contributes $13 \%$ to GDP ${ }^{1}$. In most cases textile wastewater disposed to the water basins without treatment or ineffective treatment sometimes brings about disaster to people, plants, rivers and the eco-system.

Azo dyes represent the largest class of dyes used in textile industries, in different stages. This dye containing wastewater treatment technologies aim at achieving: color removal and reduction of TDS, BOD and COD. Treatment processes include physical, chemical and biological; yet they have merits and limitations. Some conventional physico-chemical processes such as adsorption, coagulation, sedimentation and advanced oxidation, have been used to treat dye containing wastewater ${ }^{2-4}$. Although higher dye removal can be achieved, physico-chemical methods have some disadvantages, including high cost. Alternatively, biological treatment may present a relatively inexpensive way to remove dyes from wastewater ${ }^{5}$, but they needed larger space and high installation cost.

All the conventional wastewater treatment is usually the most energy-intensive unit process and required a mass amount of energy. Some of this energy can be recovered by using Microbial Fuel Cell (MFC) as a source of sustainable energy using either of low or negative economic value such as wastewater. MFCs are special types of biofuel cells, producing electric power by utilizing microorganisms ${ }^{6,7}$. Besides producing electricity, an objective of these systems is also to treat pollutants such as nitrates, sulfide and sulfates ${ }^{8-10}$.

Recently, several studies have focused on the treatment of azo dye containing wastewater by MFC. Some authors ${ }^{11,12}$ investigated the simultaneous azo dye degradation and bioelectricity generation using microbial fuel cell.

In the present work, two-chamber MFC was run by using the textile commercial dye Yellow Cibacron-2G (YC). The effect of the dyes concentration on the microbial fuel cell performance has been studied. The influence of other parameters, substrate concentration, $\mathrm{pH}$ and the catholyte solution for the MFC performance has also been inspected. The effect of dye decolorization and COD removal efficiency on MFC performance was examined by recording the variation of voltage, and current density produced from MFC.

\section{MATERIALS AND METHODS}

Dye

The dye Yellow Cibacron-2G (Clariant, India) was procured from the local textile industry and used without further treatment. The chemical structure is shown in Fig. 1.

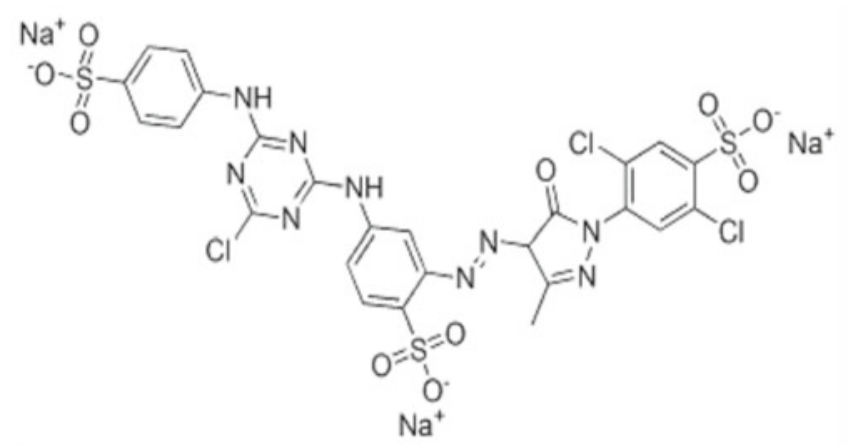

Figure 1. Molecular structure of Yellow Cibacron-2G 


\section{MFC configuration and operation}

Two MFC chambers were designed and fabricated using pet bottles in our laboratory. The fuel cell consisted of two equal volume $(0.50 \mathrm{~L})$ chambers for anode and cathode separated by proton exchange membrane (Nafion, a highly selective permeability of protons). Nafion was fixed between the washers and clamped in the hollow tube (50 mm diameter) attaching both chambers (shown in Fig. 2). Plain graphite rods (surface area of $28 \mathrm{~cm}^{2}$ ) without any coating were used as electrodes for both anode and cathode. The electrodes were positioned at a distance of $6 \mathrm{~cm}$ on either side of PEM. Copper wires were used as contact with electrodes after carefully sealing the contact area with 'epoxy' material. Prior to use the electrodes were soaked in deionized water for a period of $24 \mathrm{~h}$.

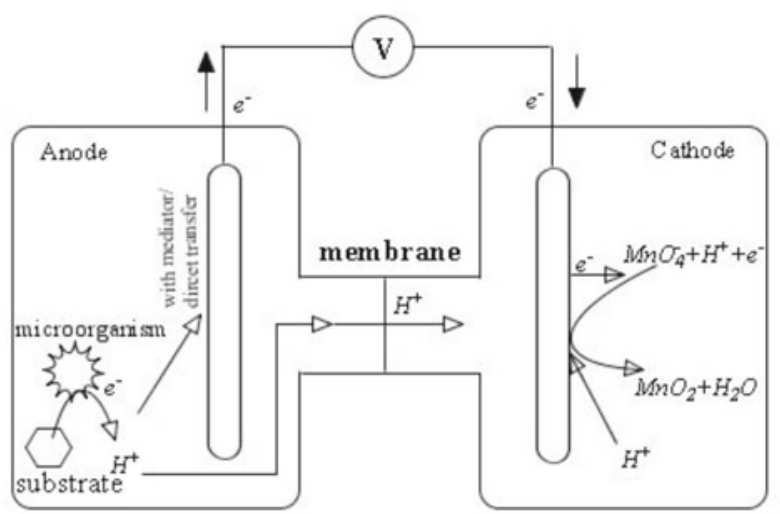

Figure 2. Two chamber microbial fuel cell with schematic details

\section{Operation of MFC}

The anodic chamber prior to startup was inoculated by the designed synthetic wastewater which was composed of dye, glucose and powdered sludge prepared from the local drainage wastewater. After that anode chambers of the MFCs were placed under an anaerobic condition with the prepared feed for a period of one day as control. Potassium permanganate was used as catholyte solutions or the terminal electron acceptors in the cathode compartment. A series of experiments was conducted to investigate the performance of the MFC with respect to decolorization of dye and electricity generation from organic carbon sources. In the first experiment, MFC was tested at different dye concentrations of 300 to $900 \mathrm{mg} / \mathrm{L}$ to investigate the effect of dye concentration on dye decolorization and electricity generation. Furthermore, the effect of glucose concentration and $\mathrm{pH}$ monitoring in the anode chamber was also conducted. Latterly, the MFCs were compared with the different catholyte solution on electricity generation. The MFCs were all operated with a fixed load $(10 \Omega)$ at an ambient temperature of $28 \pm 2^{\circ} \mathrm{C}$.

\section{Analytics and calculations}

Current and voltage were recorded with a fixed resistance by a precise digital multimeter (FL-9205A, SHEN-ZHENXL Electronic Co. Ltd, China). Power was calculated from the relation of $P=I V$, where, $I$ and $V$ represents current (A) and voltage (V), respectively. Power and current density were calculated by dividing the obtained power and current by the anode surface area $\left(\mathrm{m}^{2}\right)$. Decolorization, COD and $\mathrm{pH}$ were monitored in the anodic chamber of MFC during operation according to the standard methods ${ }^{13}$.

\section{RESULT AND DISCUSSION}

\section{Effect of dye concentration on MFC performance}

To investigate the effect of initial dye concentration of YC, anode chambers of three MFCs were charged with different solutions having a fixed concentration of substrate and changeable concentrations of the dye. The substrate (glucose) concentration was kept fixing at $300 \mathrm{mg} / \mathrm{L}$, and the variable mediator (YC) concentrations were in the range of 300 to $1200 \mathrm{mg} / \mathrm{L}$. Figure 3 shows the current density $\left(\mathrm{A} / \mathrm{m}^{2}\right)$ generated for each case during $96 \mathrm{hr}$ of operation.

A steady increase in power yield was observed, which might be attributed to the adaptation tendency of the inoculated microflora for the new microenvironment of the fuel cells. Though, current density was significantly decreased by the addition of reactive dye at a concentration up to $1200 \mathrm{mg} / \mathrm{L}$. This result indicates that the activity of electricity generating bacteria in MFCs was inhibited and could not sustain with a higher tolerance of $\mathrm{YC}$.

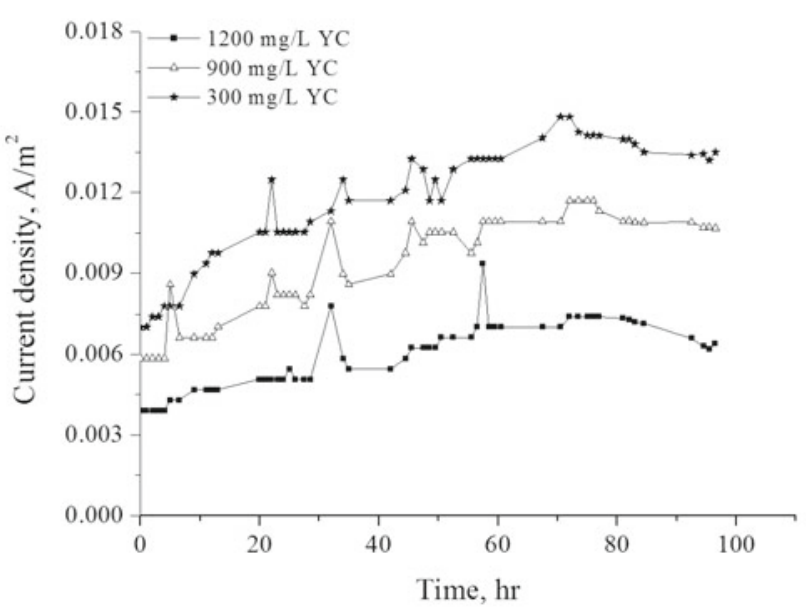

Figure 3. The effect of dye concentration in electricity generation $(0,300$, and $600 \mathrm{mg} / \mathrm{L}$ dye with $300 \mathrm{mg} / \mathrm{L}$ glucose in anode and $200 \mathrm{mg} / \mathrm{L}$ of $\mathrm{KMnO}_{4}$ in cathode at room temperature over $96 \mathrm{hr}$ operation

\section{Effect of substrate concentration on MFC performance}

The experiments were conducted in which the concentration of glucose in the anode chamber was varied from 0 to $900 \mathrm{mg} / \mathrm{L}$ with the fixed dose of the dyes at 300 $\mathrm{mg} / \mathrm{L}$. The cathode chamber was charged with $200 \mathrm{mg} / \mathrm{L}$ concentration of $\mathrm{KMnO}_{4}$ solution, and the current density was recorded throughout $96 \mathrm{hr}$ operation by connecting the circuit with $10 \Omega$ fixed resistances. The results are presented in Fig. 4a. As shown in Fig. 4a the absence of substrate results in very poor current density. As the glucose concentration increased from 0 to $300 \mathrm{mg} / \mathrm{L}$, the current density increased from $0.001 \mathrm{~A} / \mathrm{m}^{2}$ to $0.015 \mathrm{~A} / \mathrm{m}^{2}$ after $90 \mathrm{~h}$ of operation and with the further increase in 


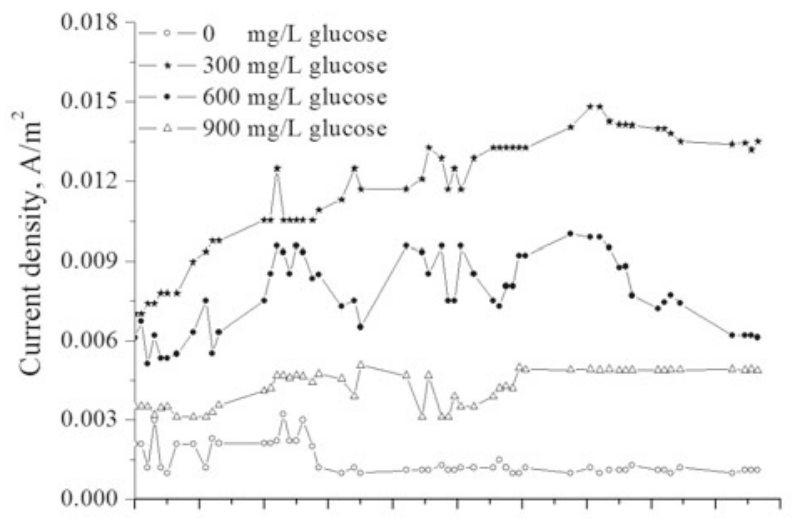

Figure 4a. Effect of substrate (glucose) concentration in electricity generation $(0,300,600$ and $900 \mathrm{mg} / \mathrm{L}$ glucose with $300 \mathrm{mg} / \mathrm{L} \mathrm{YC}$ in anode and $200 \mathrm{mg} / \mathrm{L}$ of $\mathrm{KMnO}_{4}$ in cathode at room temperature over $96 \mathrm{hr}$ operation

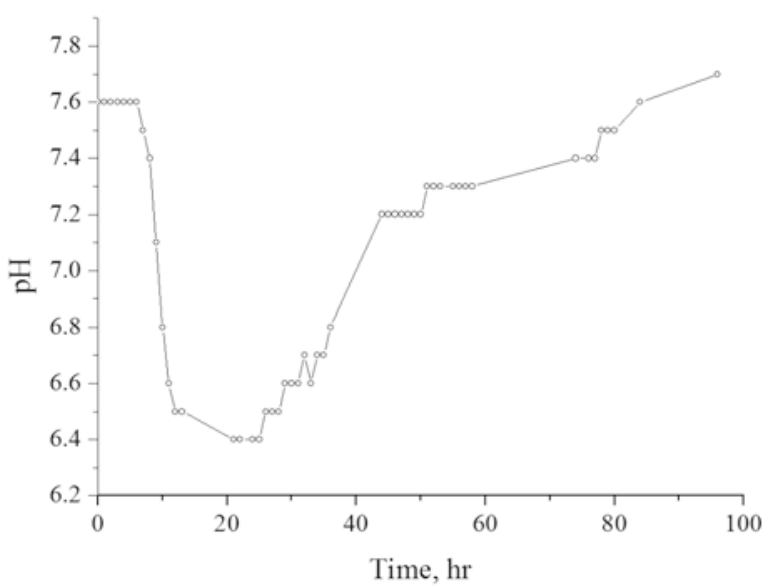

Figure 4b. Variation of $\mathrm{pH}$ in the anode chamber $(300 \mathrm{mg} / \mathrm{L}$ glucose with $300 \mathrm{mg} / \mathrm{L} \mathrm{YC} \mathrm{in} \mathrm{anode} \mathrm{and} 200 \mathrm{mg} / \mathrm{L}$ of $\mathrm{KMnO}_{4}$ in cathode at room temperature)

glucose concentration from 600 to $900 \mathrm{mg} / \mathrm{L}$ the current density decreased from $0.009 \mathrm{~A} / \mathrm{m}^{2}$ to $0.004 \mathrm{~A} / \mathrm{m}^{2}$.

Microorganisms generate electricity due to the consumption of glucose in the aerobic conditions, where they produce carbon dioxide and water. However, when oxygen is not present they produce carbon dioxide, protons and electrons as described in reaction $1^{14,15}$ :

$\mathrm{C}_{6} \mathrm{H}_{12} \mathrm{O}_{6}+\mathrm{H}_{2} \mathrm{O} \rightarrow 6 \mathrm{CO}_{2}+24 \mathrm{H}^{+}+24 e^{-}$

According to Hideki Sakai et al. ${ }^{16}$ the current increased with the increase in the glucose concentration. However, for the higher glucose concentration this may cause the increase of the proton concentration within the immobilized layer by the following glucose oxidation reaction (reaction 2) which leads to suppression of the enzymatic activities.

Glucose $\rightarrow$ Gluconolactone $+2 \mathrm{H}^{+}+e^{-}$

That means, in comparison with various glucose concentrations in the anode, higher glucose concentration exhibited lower current generation. As a result, to achieve the maximum electricity generation, MFC should be operated with the optimum concentration level.

The $\mathrm{pH}$ in the anode chamber was monitored for the cell operating with $300 \mathrm{mg} / \mathrm{L}$ glucose, and the data were presented in Fig. 4b. As current increases, the $\mathrm{pH}$ of an anode chamber decreased due to proton generation and maintained a steady value around $30 \mathrm{hr}$ indicated the proton accumulation or transport phenomenon. After $30 \mathrm{hr}$ operation, the $\mathrm{pH}$ started increasing slowly and reached the initial value, in consequence of proton transportation to the cathode chamber. The maximum electricity was achieved at $\mathrm{pH}$ value around 7 , and this result agreed with the results reported by Ren et al. ${ }^{17}$.

\section{Effect of catholyte on MFC performance}

In the two-chamber MFC, different catholyte solutions such as potassium permanganate and potassium dichromate were used as electron acceptors to generate electricity. Two cells were operated in batch mode by adding glucose and $\mathrm{YC}$ concentration of $300 \mathrm{mg} / \mathrm{L}$ in each anode chamber. The two different catholyte solutions of $\mathrm{KMnO}_{4}$ and $\mathrm{K}_{2} \mathrm{Cr}_{2} \mathrm{O}_{7}$ respectively, at $200 \mathrm{mg} / \mathrm{L}$ concentration were compared to sort out, which catholyte solution generates maximum electricity. All these experiments were done in both open and closed circuits. The current density after $50 \mathrm{hr}$ of operation was observed as $0.012 \mathrm{~A} / \mathrm{m}^{2}$, whereas the cell with $\mathrm{K}_{2} \mathrm{Cr}_{2} \mathrm{O}_{7}$ catholyte solution produced three times lower discharge current at the same period (Fig. 5).

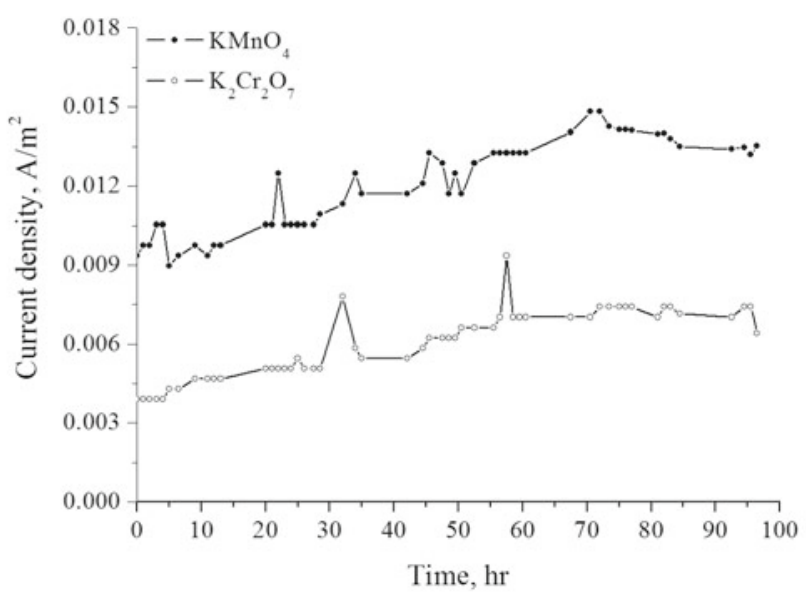

Figure 5. Comparison of discharge current generation in two-chamber MFC using different catholyte solutions (Cathode: $\mathrm{KMnO}_{4}$ and $\mathrm{K}_{2} \mathrm{Cr}_{2} \mathrm{O}_{7}$ solutions, 200 $\mathrm{mg} / \mathrm{L}$ each; Anode: glucose and dye concentrations, $300 \mathrm{mg} / \mathrm{L}$ each; Current was measured using $22.5 \Omega$ external resistance)

The $\mathrm{pH}$ adjustment was not made as it was reported by $\mathrm{Zhao}$ et al.; $\mathrm{Li}$ et al. ${ }^{18,19}$ and that low $\mathrm{pH}$ values lead to an increase of the cathode potential. The reaction 3-5 also illustrates the fact in that acidic condition and indicates $\mathrm{MnO}_{4}^{-}$has much higher oxidation potential than in alkaline conditions ${ }^{20}$.

$$
\begin{aligned}
& \mathrm{MnO}_{4}^{-}+4 \mathrm{H}^{+}+3 e^{-} \rightarrow \mathrm{MnO}_{2}+2 \mathrm{H}_{2} \mathrm{O} ; E^{0}=1.7 \mathrm{~V} \\
& \mathrm{MnO}_{4}^{-}+2 \mathrm{H}_{2} \mathrm{O}+3 e^{-} \rightarrow \mathrm{MnO}_{2}+4 \mathrm{OH}^{-} ; E^{0}=0.59 \mathrm{~V} \\
& \mathrm{Cr}_{2} \mathrm{O}_{7}^{2-}+14 \mathrm{H}^{+}+6 e^{-} \rightarrow 2 \mathrm{Cr}^{3+}+7 \mathrm{H}_{2} \mathrm{O} ; E^{0}=1.33 \mathrm{~V}
\end{aligned}
$$

\section{Dye removal and decolorization efficiency of MFC}

Two-Chamber MFC was continuously monitored for the COD removal and decolorization of textile dye to specify the potentiality of fuel cell to act as wastewater treatment unit. Three cells having the dye concentrations of 300,600 and $900 \mathrm{mg} / \mathrm{L}$ along with $300 \mathrm{mg} / \mathrm{L}$ of glucose 


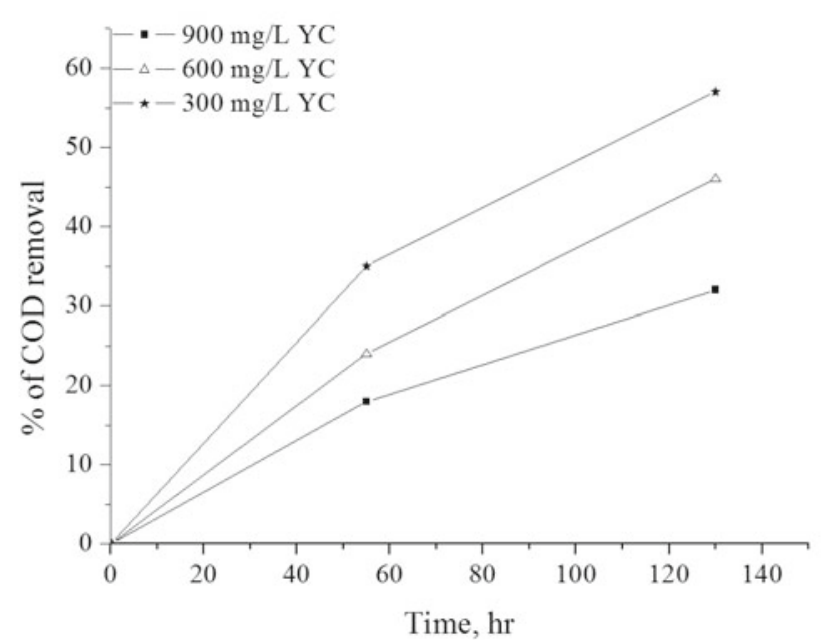

Figure 6. Variation of COD removal with time

at anode and $\mathrm{KMnO}_{4}$ concentration of $200 \mathrm{mg} / \mathrm{L}$ in each cathode chamber was operated.

In order to clarify the changes in the molecular and structural characteristics of YC resulting from the treatment process, the change in the UV-vis spectra of wastewater was recorded (Fig. 7a).

The UV-vis spectra showed that the YC azo band centered at $510 \mathrm{~nm}$ decreased considerably after the anaerobic treatment in the anode chamber. This suggests that most of the $-\mathrm{N}=\mathrm{N}-$ bonds were cleaved by the anaerobic treatment ${ }^{21}$.

Decolorization of azo dyes by bacteria could be due to adsorption by microbial cells or to biodegradation ${ }^{\mathbf{5 , 2 2}}$. In adsorption, cells may become deeply colored because of adsorbing dyes, whereas those retaining their original colors are accompanied by the occurrence of biodegradation. The microbial consortium remained at its original color after batch decolorization in this study, indicating that the color removal was actually primarily incurred due to biodegradation rather than biosorption by living cells. Low decolorization in the case of higher dye concentration suggests the suppression of the microbial. It is evident from the experimental data that the MFC facilitated both the substrate removal and power generation.

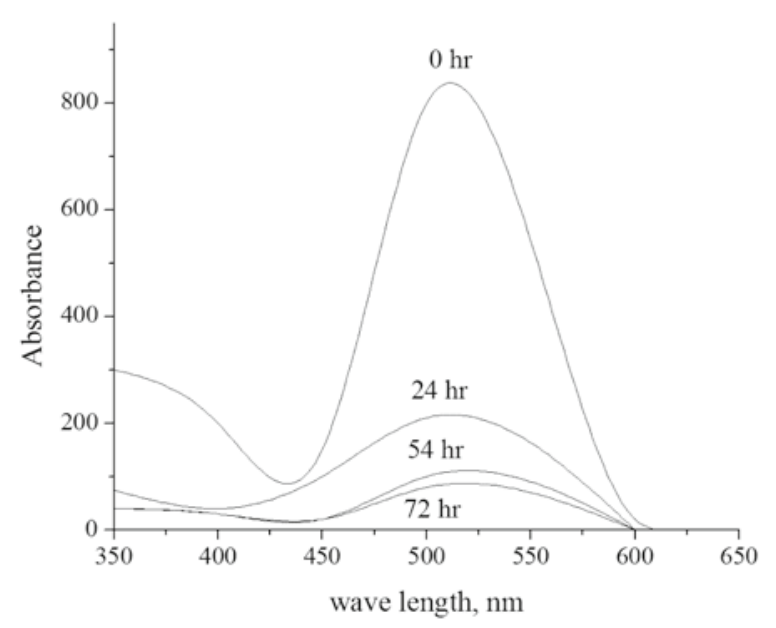

Figure 7a. UV-vis spectra of wastewater containing YC in effluent of anode chamber

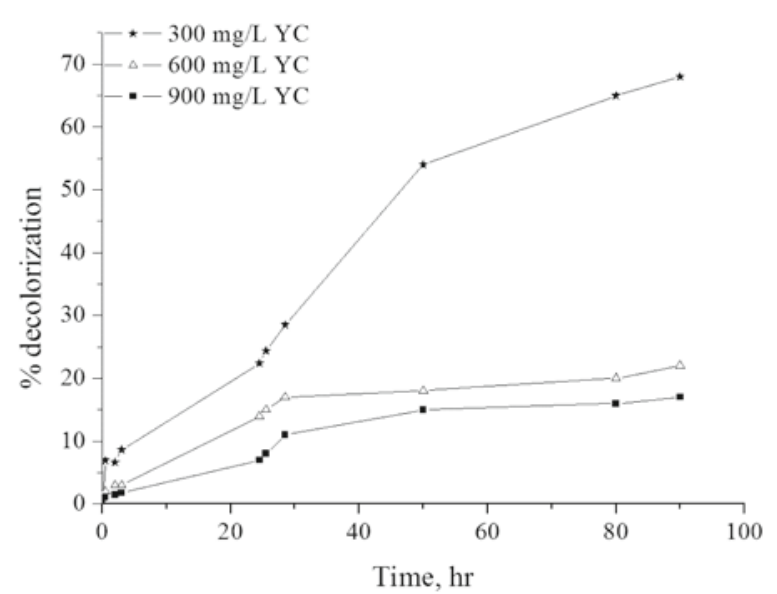

Figure 7b. Effect of the initial dye concentration $(\mathrm{mg} / \mathrm{L})$ on the decolorization efficiency of YC in MFC at an external resistance of $106 \Omega$, with glucose (300 $\mathrm{mg} / \mathrm{L}$ ) used as substrate

\section{Polarization curve}

Figure 8 displayed the maximum power density of $2.76 \mathrm{~mW} / \mathrm{m}^{2}$ for the cell operating with $300 \mathrm{mg} / \mathrm{L} \mathrm{YC}$ and glucose, respectively at the anode chamber. For all the cases, power densities showed an incremental trend with decreasing external resistance and reaches to a peak value. After that, the power densities begin to fall down with increasing current density. Current generation showed a decreasing trend with the increase in resistance and is consistent with the reported literature by Mohan et al. ${ }^{9}$, which indicated a typical fuel cell behavior. At higher resistance used, relatively less power density was observed.

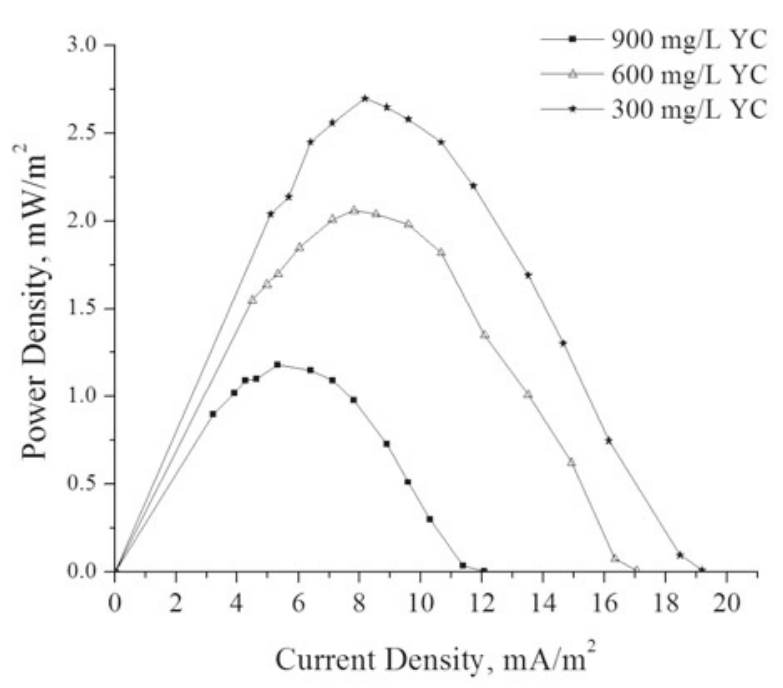

Figure 8. Polarization curve performed at different dye concentration $(\mathrm{mg} / \mathrm{L})$ in $\mathrm{MFC}$ at an external resistance of 22.5 , with glucose $(300 \mathrm{mg} / \mathrm{L})$ used as substrate

\section{CONCLUSIONS}

Microbial Fuel cell was fabricated and constructed with cheap and locally available materials. Upon investigation of different catholyte solutions, $\mathrm{KMnO}_{4}$ solution exhibited high-power output than $\mathrm{K}_{2} \mathrm{Cr}_{2} \mathrm{O}_{7}$. Moreover, the effect of various dyes and glucose concentrations on MFC performance, percentage removal of COD and decolorization were studied as well as found that 
optimum glucose and azo dye concentration must be necessary to achieve high electricity production and efficient wastewater treatment. At optimum glucose and dye concentrations ( $300 \mathrm{mg} / \mathrm{L}$ for both) this system can simultaneously generate electricity of about $0.03 \mathrm{~A} / \mathrm{m}^{2}$ and remove $57 \%$ of COD from the wastewater.

\section{LITERATURE CITED}

1. Roy, R., Fakhruddin, A.N.M., Khatun, R., Islam, M.S., Ahsan, M.A., Neger, A.J.M.T. (2010). Characterization of Textile Industrial Effluents and its Effects on Aquatic Macrophytes and Algae. Bangladesh J. Sci. Ind. Res. 45 (1), 79-84. DOI: 10.3329/bjsir.v45i1.5187.

2. Alaton, I.A., Balcioglu, I.A. \& Bahnemann, D.W. (2002). Advanced oxidation of a reactive dye bath effluent: Comparison of $\mathrm{O}_{3}, \mathrm{H}_{2} \mathrm{O}_{2} / \mathrm{UVC}$ and $\mathrm{TiO}_{2} / \mathrm{UVA}$ processes. Water Res. 36, 1143-1154. DOI: 10.1016/S0043-1354(01)00335-9.

3. Sarasa, J., Roche, M.P., Ormad, M.P., Gimeno, E., Puig, A. \& L. Ovelleiro, J. (1998). Treatment of a wastewater resulting from dyes manufacturing with ozone and chemical coagulation. Water Res. 32, 2721-2727. DOI: 10.1016/S0043-1354(98)00030-X.

4. Vandevivere, P.C., Bianchi, R. \& Verstraete, W. (1998). Treatment and reuse of wastewater from the textile wet-processing industry: review of emerging technologies. J. Chem. Technol. Biotechnol.72, 289-302. DOI: 10.1002/(SICI)10974660(199808)72: 4< 289::AID-JCTB905>3.0.CO;2-\#.

5. DosSantos, A.B., Cervantes, F.J. \& Van-Lier, J.B. (2007). Review paper on current technologies for decolourisation of textile wastewaters: perspectives for anaerobic biotechnology. Bioressour. Technol . 98, 2369-2385. DOI: 10.1016/j.biortech. 2006. 11. 013.

6. Logan, B.E. \& Regan, J.M. (2006). Microbial fuel cells: Challenges and applications. Environ. Sci. Technol. 41, 5172-5180. DOI: 10.1021/es0627592.

7. Park, D.H. \& Zeikus, G. (2003). Improved fuel cell and electrode designs for the producing electricity from microbial degradation. Biotechnol. Bioeng. 81, 348-355. DOI: 10.1002/ bit.10501.

8. Rabaey, K., Boon, N., Siciliano, S.D., Verhaege, M. \& Verstraete, W. (2004). Biofuel cells select for microbial consortia that self-mediate electron transfer. Appl. Environ. Microbiol. 70 (5373-5382). DOI: 10.1128/AEM.70.9.5373-5382.2004.

9. Mohan, S.V., Saravanan, R., Veer, S.R., Mohanakrishna, G. \& Sarma, P.N. (2006). Bioelectricity production from wastewater treatment in dual chambered microbial fuel cell (MFC) using selectively enriched mixed microflora: Effect of catholyte. Bioresour. Technol. 99 (3), 596-600. DOI: 10.1016/j. biortech.2006.12.026.

10. Pant, D., Bogaert, G.V., Diels, L. \& Vanbroekhoven, K. (2010). A review for the substrate used in microbial fuel cell (MFCs) for sustainable energy production. Bioresour. Technol. 101 (6), 1533-1543. DOI: 10.1016/j.biortech.2009.10.017.

11. Sun, J., Hu, Y.Y., Bi, Z. \& Cao, Y. (2009). Simultaneous decolorization of azo dye and bioelectricity generation using a microfiltration membrane air-cathode singlechamber microbial fuel cell. Bioresour. Technol. 100, 3185-3192. DOI: 10.1016/j. biortech.2009.02.002.

12. Ieropoulos, I.A., Greenman, J., Melhuish, C. \& Hart, J. (2005). Comparative study of three types of microbial fuel cell. Enzyme Microb. Tech. 37, 238-245. DOI: 10.1016/j. enzmictec.2005.03.006.

13. APHA, (1998). Standard methods for the examination of water and wastewater (20th ed). Washington DC, USA: American Public Health Association.

14. Bennetto, (1990). Electricity generation by microorganisms. Biotechnology Education. 1 (4), 163-168.

15. Logan, B.E., Hamelers, B., Rozendal, R., Schroder, U., Keller, J., Freguia, S., Aelterman, P., Verstraete, W. \& Rabaey,
K. (2006). Microbial fuel cells: Methodology and Technology. Environ. Sci. Technol. 40, 5181-5192. DOI: 10.1021/es0605016.

16. Ren, Z.Y., Ward, T.E. \& Regan, J.M. (2007). Electricity production from cellulose in a microbial fuel cell using a defined binary culture. Environ. Sci Technol. 41 (13), 4781-4786. DOI: 10.1021/es070577h.

17. Hideki, S., Takaaki, N., Tokita, Y., Hatazawa, T., Tokuji, I., Tsujimura, S. \& Kano, K. (2009). A high-power glucose/ oxygen biofuel cell operating under quiescent conditions. Energy Environ. Sci. 2, 133-138. DOI: 10.1039/B809841G.

18. Zhao, F., Hamisch, F., Schroder, U., Scholz, F., Bogdanoff, P. \& Hermann, I. (2005). Application of pyrolysed iron (II) phthalocyanine and CoTMPP based oxygen reduction catalysts as cathode materials in microbial fuel cells. Electrochem. Commun. 7, 1405-1410. DOI: 10.1016/j.elecom.2005.09.032.

19. Li, Z.J., Zhang, X.W., Zeng, Y.X. \& Lei, L.C. (2009). Electricity Production by an overflow-type wetted wall microbial fuel cell. Bioresour. Technol.100, 2551-2555. DOI: 10.1016/j. biortech.2008.12.018.

20. You, S., Zhao, Q., Zhang, J., Jiang, J. \& Zhao, S. (2006). A microbial fuel cell using permanganate as the cathodic electron acceptor. J. Power Sour. 162, 1409-1415. DOI: 10.1016/j. jpowsour.2006.07.063.

21. Pandey, A., Singh, P. \& Iyengar, L. (2007). Bacterial decolorization and degradation of azo dyes. Int. Biodeterior. Biodegrad. 59, 73-84. DOI: 10.1016/j.ibiod.2006.08.006.

22. Sani, R.K. \& Banerjee, U.C. (1999). Decolorization of triphenylmethane dyes and textile and dye-stuff effluent by Kurthia sp. Enzyme Microb. Technol. 24, 433-437. DOI: 10.1016/S0141-0229(98)00159-8. 